\title{
URETHRAL CATHETER REMOVAL 7 OR 14 DAYS AFTER RADICAL RETROPUBIC PROSTATECTOMY: CLINICAL IMPLICATIONS AND COMPLICATIONS IN A RANDOMIZED STUDY
}

\author{
Carlos Ary Vargas Souto, Ernani Luis Rhoden, Rafael De Conti, Mário Chammas \\ Jr., Sandro Eduardo Laste, Alexandre Fornari, Eduardo Porto Ribeiro, Liana \\ Scholl, Claudio Teloken and José Carlos Stumpf Souto
}

SOUTO CAV et al. Urethral catheter removal 7 or 14 days after radical retropubic prostatectomy: clinical implications and complications in a randomized study. Rev. Hosp. Clin. Fac. Med. S.Paulo 59(5):262-265, 2004.

PURPOSE: To evaluate the hypothesis that a 7-day period of indwelling catheter after radical retropubic prostatectomy is effective and safe without the need of performing cystography.

METHODS: In the period from January of 2000 to July of 2002, 73 patients underwent radical retropubic prostatectomy, and these patients were prospectively randomized in 2 groups: Group 1-37 patients who had the urethral catheter removed 7 days after the procedure, and Group 2-36 patients who had the catheter removed 14 days after the surgery. The 2 groups were similar, the surgeons and the technique were the same, and no cystography was performed to evaluate the presence of leaks.

RESULTS: Two patients in Group 1 had bleeding and clot retention after having the catheter taken out in the seventh postoperative day and were managed by putting the catheter back in for 7 more days. Two patients in Group 2 developed bladder neck stricture and were treated by bladder neck incision with success. The continence rate was the same, with 2 cases of incontinence in each group. About 2 pads a day were used by the patients with incontinence. The average follow-up was 17.5 months (12-36 months). No urinary fistula, urinoma, or pelvic abscesses developed after catheter removal. Two patients were excluded from the analysis of this series: 1 died with a pulmonary embolus in the third postoperative day, and 1 developed a urinary suprapubic fistula before catheter withdrawal, which was maintained for 16 days.

CONCLUSION: Withdrawal of the urethral catheter 7 days after radical retropubic prostatectomy, without performing cystography, has a low rate of short-term complications that are equivalent to withdrawal 14 days after the surgery.

KEY WORDS: Prostate cancer. Radical prostatectomy. Urethral catheterization. Prostate. Catheter withdrawal.

Radical prostatectomy is a standard procedure for the treatment of localized prostate cancer in patients in good health who are under 70 years of age. ${ }^{1}$ Until 1982, when Walsh et al. ${ }^{2}$ introduced a refined technique for performing radical retropubic prostatectomy (RRP), this procedure was not widely used because of the high rates of associated morbidity and mortality.

Standard reconstructive technique after RRP involves the placement of a urethral catheter for stenting the vesicourethral anastomosis and bladder drainage. ${ }^{3}$ There is some debate in the literature about how many days the urethral catheter should be left in af-

From the Division of Urology of the Santa Casa of Porto Alegre (ISCMPA) and Federal Foundation of Porto Alegre (FFFCMA) Porto Alegre/Rio Grande do Sul, Brazil.

Email: cavsouto@hotmail.com Received for publication on February 27, 2004 ter RRP. In the early description of this procedure, 21 to 30 days was the period normally advocated. Subsequent studies $^{3-5}$ showed that 14 days was safe for this purpose.

More recently, it has been reported that it is safe to remove catheters in most patients 3 to 4 days after RRP if a cystogram demonstrates no extravasation. ${ }^{6} \mathrm{Nadu}$ et al. ${ }^{7}$ demonstrated that in 2 to 4 days after laparoscopic RRP, an absence of contrast leakage was ob- 
served in $84.9 \%$ of the patients, and that urethral catheter removal could be then safely performed.

The difficulty and disconfort associated with routine cystography stimulated us to perform this randomized study in which we compare the results of catheter removal 7 and 14 days after RRP without using cystographic evaluation.

\section{PATIENTS AND METHODS}

In this study, approved by the Institutional ethics committee, we evaluated in a randomized approach the results of catheter removal 7 and 14 days after RRP, performed in 73 consecutive patients. The study was undertaken from January of 2000 to July of 2002 at the Division of Urology at Santa Casa of Misericordia of Porto Alegre.

The mean age of the group of patients was 62 years, ranging from 50 to 73 years.

The standard retropubic approach for radical prostatectomy (RRP), as described by Walsh, ${ }^{2,4,5}$ was adopted in all cases. Although technical details varied from surgeon to surgeon, the bladder neck usually was not preserved, being reconstructed with a longitudinal chromic catgut suture. The anastomosis between the membranous urethra and the bladder was done with 4 to 6 2-0 or 3-0 Monocryl $^{\mathrm{R}}$ interrupted stitches. A 2-way 20 Fr. Foley catheter was left indwelling.

The patients were randomized into 2 groups regarding the catheter removal after RRP: Group 1 comprised 37 patients in which urethral catheter was removed 7 days after surgery; Group 2 comprised 36 patients who had the urethral catheter removed 14 days after RRP.

Complications and continence in the immediate and late postoperative period were assessed in a follow-up that ranged from 2 to 30 months (mean
17.5 months). Continence was defined as pad-free status.

The chi-square test and Student $t$ test were applied to compare the group characteristics as well as the incidence of complications between the groups, with critical values and statistical significance at $P<.05$.

\section{RESULTS}

The mean age between the groups was similar $(P>.05)$. There were also no differences regarding the prostatespecific antigen, tumor stage, operating time, amount of bleeding, or volume of blood transfusion between the 2 groups of patients $(P>.05)$. These values are shown in Table 1.

Two $(5.4 \%)$ patients in the group undergoing catheter withdrawal after 7 days (Group 1) developed hematuria and urinary retention by clots, which was safely managed by an easily performed urethral catheterization and then maintained for 7 more days. In the group undergoing urethral catheter withdrawal after 14 days (Group 2), vesical neck stricture occurred in 2 $(5.5 \%)$ cases, which wAS treated by transurethral endoscopic neck incision. Urinary incontinence at the end of the study was observed in 2 patients of each group $(5.4 \%$ versus $5.5 \%$; $P$ $>.05$ ) (Table 2).

\section{DISCUSSION}

Postoperative morbidity related to RRP is a factor that deserves important consideration, especially when this procedure is compared to other therapeutic modalities. ${ }^{3}$ However, the good results regarding the cure of the disease as well as in the reduction of the complications related to the surgery, have recently inspired debate about the possible early withdrawal of the urethral catheter, giving to the individual the possibility of a quicker return to his activities as well as the potential of the reduction of the occurrence of complications related to a longer term of an indwelling urethral catheter. ${ }^{3}$ Regarding concerns about complications, the association of longer periods of an indwelling urethral catheter to urethral and bladder neck stenosis is well recognized, and these problems are often not easy to treat. ${ }^{6,8}$

Table 1 - Comparison of the general characteristics of the study groups of catheter removal 7 and 14 days after radical retropubic prostatectomy (RRP).

\begin{tabular}{lccc}
\hline & \multicolumn{2}{c}{ Catheter removal after RRP } \\
& 7 days & 14 days & $P$ \\
\hline Number & 37 & 36 & \\
Age, mean (range) y & $64 \pm 7.3(50-77)$ & $61 \pm 7.3(49-73)$ & 0.1 \\
PSA, mean, ng/dL & $9.9 \pm 10.9$ & $10.2 \pm 6.9$ & 0.9 \\
Operating time, mean, min & $191 \pm 75.6$ & $189 \pm 51.5$ & 0.9 \\
\hline
\end{tabular}

PSA $=$ prostate-specific antigen; $\mathrm{RRP}=$ radical retropubic prostatectomy

Table 2 - Complications after catheter removal 7 and 14 days after radical retropubic prostatectomy (RRP).

\begin{tabular}{|c|c|c|c|}
\hline & \multicolumn{3}{|c|}{ Catheter removal after RRP } \\
\hline & 7 days & 14 days & $P$ \\
\hline Urinary retention + hematuria, $\mathrm{n}(\%)$ & $2(5.4)$ & $-(0)$ & 0.5 \\
\hline Vesical neck stenosis, n (\%) & $-(0)$ & $2(5.5)$ & 0.2 \\
\hline Urinary incontinence, $\mathrm{n}(\%)$ & $2(5.5)$ & $2(5.5)$ & 1.0 \\
\hline
\end{tabular}


Previous studies have demonstrated that early decatheterization after cystography was accompanied by an absence of leaks and could be performed safely and without significant complications. ${ }^{8-11}$ Hewitt et al. ${ }^{12}$ demonstrated in perineal radical prostatectomies and, more recently, Nadu et al. ${ }^{7}$ demonstrated in a large series of laparoscopic radical prostatectomy that very early urethral catheter removal (4 days after surgery) was possible using gravitational cystography with an absence of leaks at the urethrovesical anastomosis. Nevertheless, it is important to note that cystography sometimes causes complications, and involves extra cost and can sometimes be an uncomfortable procedure.

Based on a previous study with a high rate of success with early urethral catheter removal (4 to 5 days after surgery) after cystography, demonstrating absence of leaks at the level of the urethrovesical anastomosis, ${ }^{6}$ we decided to compare removing the catheter 7 days after RRP against the standard 14-day catheter withdrawal period, without performing cystography.

The results of this evaluation revealed that there was not a significantly higher incidence of complications in the group with early decatheterization when compared with the group managed in the standard manner. Similar results were reported by Santis et al. ${ }^{13}$ who removed the catheter successfully 8 or 9 days after the surgery without cystography. Also, these results are to some extent supported by the study of Nadu et al. ,? who demonstrated in a large series of cases the absence of leaks in $84.9 \%$ of the individuals who underwent cystography 2 to 4 days after radical prostatectomy.

Also, it is important to emphasize that while complications such as uri- nomas or stenosis of the urethrovesical anastomosis were not observed in the 7-day-urethral-catheter-removal group, an undesirable stenosis of the urethrovesical anastomosis developed in 2 cases in the 14-day-catheter-removal group. Also, it is our opinion that the cases of hematuria and urinary retention are acceptable events, since these can be easily solved by reposition of the catheter for longer periods. ${ }^{6,7}$

In summary, considering some potentially limiting factors such as the relatively small size of the present series and the short period of follow-up, the results of the present study indicate that a period of 7 days of catheterization is probably enough after RRP, since catheter withdrawal after this period was not associated with a higher rate of complications than were experienced by the group of patients who had their catheters removed at the standard fashion (14 days after surgery).

\section{RESUMO}

SOUTO CAV e col. Sete ou quatorze dias para a retirada da sonda vesical de demora após prostatectomia radical retropúbica: implicações clínicas e complicações em um estudo randomizado. Rev. Hosp. Clin. Fac. Med. S. Paulo 59(5):262-265, 2004.

OBJETIVO: Avaliar a hipótese de que um período de sete dias de sonda vesical de demora após prostatectomia radical retropúbica é efetivo e seguro, sem a necessidade da realização de cistografia.

MÉTODOS: Entre janeiro de 2000 e julho de 2002, setenta e três pacientes submetidos à prostatectomia radical retropúbica foram prospectivamente randomizados em dois grupos: grupo 1 - 37 pacientes em que a sonda vesical foi removida 7 dias após o procedimen- to e, grupo $2-36$ nos quais a sonda foi removida 14 dias após a cirurgia. Os dois grupos apresentavam características clínicas similares, os cirurgiões e técnicas foram as mesmas, e nenhuma cistografia foi realizada para avaliar a presença de vazamentos.

RESULTADOS: Dois pacientes no grupo 1 apresentaram sangramento e retenção por coágulos após a retirada da sonda no sétimo dia pós-operatório, e foram manejados através da recolocação da sonda vesical por mais 7 dias. Dois pacientes do grupo 2 desenvolveram esclerose do colo vesical e foram tratados através de incisão do colo vesical com sucesso. A taxa de continência foi a mesma, com dois casos de incontinência em cada grupo. Em torno de duas fraldas por dia eram utilizadas pelos pacientes com incontinência. O seguimento médio foi de 17.5 meses (2 - 30 meses). Não houve formação de fístula urinária, urinoma ou abcesso pélvico após a retirada da sonda vesical. Dois pacientes foram excluidos da análise desta série: um faleceu devido a embolia pulmonar no terceiro dia pós-operatório, e o outro desenvolveu fístula urinária suprapúbica antes da retirada do cateter, que foi mantido por 16 dias.

CONCLUSÃO: A retirada da sonda vesical 7 dias após a prostatectomia radical retropúbica, sem realização de cistografia, tem uma baixa taxa de complicações de curto prazo, equivalentes às da retirada da sonda aos 14 dias de pós-operatório.

UNITERMOS: Câncer de próstata. Prostatectomia radical. Sondagem vesical. Próstata. Retirada da sonda vesical. 


\section{REFERENCES}

1. Catalona WJ, Ramos CG, Carvalhal GF. Contemporary results of anatomic radical prostatectomy. CA Cancer J Clin 1999;49(5):282-96.

2. Walsh PC, Donker PJ. Impotence following radical prostatectomy: insight into etiology and prevention. J Urol 1982;128(3):4927.

3. Leibovitch I, Rowland RG, Little JS, Foster RS, Bihrle R, Donohue JP. Cystography after radical retropubic prostatectomy: clinical implications of abnormal findings. Urology 1995;46(1):7880.

4. Walsh PC. Walsh technique. In: Communication P, editor. First radical prostatectomy world summit; 2002 2002; Cleveland, Ohio: The Cleveland Clinic Foundation; 2002.

5. Walsh PC, Lepor H, Eggleston JC. Radical prostatectomy with preservation of sexual function: anatomical and pathological considerations. Prostate 1983;4(5):473-85.

6. Souto CA, Teloken C, Souto JC, Rhoden EL, Ting HY. Experience with early catheter removal after radical retropubic prostatectomy. J Urol 2000;163(3):865-6.

7. Nadu A, Salomon L, Hoznek A, Olsson LE, Saint F, de la Taille A et al. Early removal of the catheter after laparoscopic radical prostatectomy. J Urol 2001;166(5):1662-4.
8. Lepor H, Nieder AM, Fraiman MC. Early removal of urinary catheter after radical retropubic prostatectomy is both feasible and desirable. Urology 2001;58(3):425-9.

9. DeMarco RT, Bihrle R, Foster RS. Early catheter removal following radical retropubic prostatectomy. Semin Urol Oncol 2000;18(1):57-9.

10. Coogan CL, Little JS, Bihrle R, Foster RS. Urethral catheter removal prior to hospital discharge following radical prostatectomy. Urology 1997;49(3):400-3.

11. Little JS, Jr., Bihrle R, Foster RS. Early urethral catheter removal following radical prostatectomy: a pilot study. Urology 1995;46(3):429-31.

12. Hewitt A. Early catheter removal following radical perineal prostatectomy: a randomized clinical trial. Urol Nurs 2001;21(1):37-8.

13. Santis WF, Hoffman MA, Dewolf WC. Early catheter removal in 100 consecutive patients undergoing radical retropubic prostatectomy. BJU Int 2000;85(9):1067-8. 